\title{
Early Modern Media and the News in Europe. Perspectives from the Dutch Angle
}

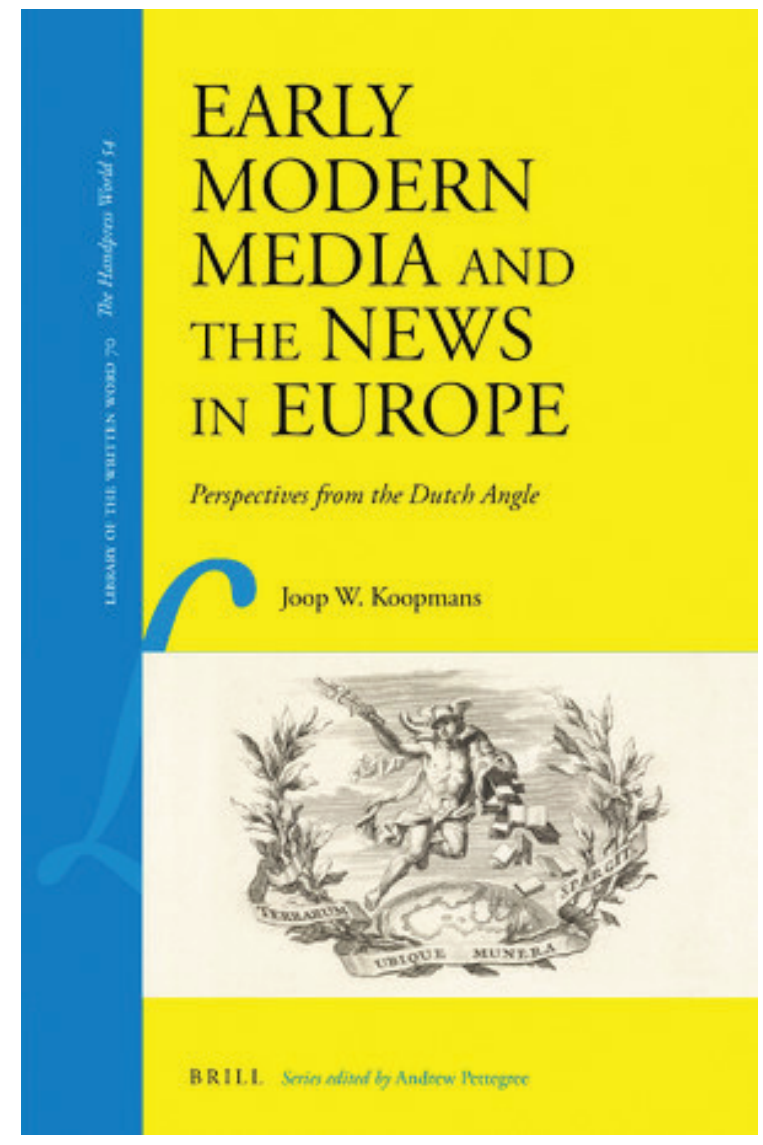

\section{Joop W. Koopmans}

Early Modern Media and the News in Europe. Perspectives from the Dutch Angle

Brill, 20I8, xviii + 36I pp., € I40, ISBN 978-90-04-37930-5

In June I6I8, Casper van Hilten began publishing the first Dutch newspaper. By $6_{5}$ I, the point at which Joop Koopmans begins Early Modern Media and the News in Europe, newspapers had taken the Dutch Republic by storm. Travelers were stunned at how common they were. One claimed, 'everyone reads them here.' A Reformed minister bemoaned that
Christians were not reading their Bibles but instead the papers: 'Published and printed on a weekly basis,' he declared in 1626 , these papers are 'read by Christians who do not bother to turn their eyes over the Scripture even once a week.' At the turn of the seventeenth century to the eighteenth, newspapers remained some of the most ubiquitous items of everyday life. Read by the masses, they tell us about the people who demanded them: how they understood themselves and how they understood the world around them. What can we know about these people from the news they demanded and consumed? Joop Koopmans, a senior lecturer at the Rijksuniversiteit Groningen specialised in history and politics in early modern Europe, devoted the last twenty years of his academic career to understanding and answering this question. Early Modern Media and the News in Europe is the fruit of such work.

In this excellent volume, Koopmans seeks to help readers understand the rise of the newspaper in the Dutch Republic and traces the narrative to I795. It considers what they tell us about Dutch culture and self-perception. As a collection of previously published essays, it is a scholarly work intended for those who have an understanding of Dutch history in general and the history of the newspaper specifically. Rather than organising the essays chronologically, beginning with the first article Koopmans wrote as a newer scholar in the early 2000 s to his most recent, the author 
and editors made the excellent choice of arranging the book thematically. It has four sections, covering news digests that condensed and reprinted previously printed news (chapters I-5), reflections on the value of newspapers to our cultural awareness (chapters 6-9), case studies from I730 to I755 (chapters IO-I2) and it concludes with a section on the importance of war to the news (chapters I3-I5). This creates of a more united seeming book, rather than a disparate collection of arbitrary articles.

Though it is an academic publication, the first chapter helpfully introduces the topic such that general readers can more fully understand the volume. In the first section Koopman reflects on the importance of news digests - periodicals that were printed every six months or so that condensed news reports and repackaged them so they could be stored long term. It is not in the least ironic that a book that includes a section on news digests is itself a compilation of work done previously. Koopmans helps modern readers understand the importance of not only these news digests but of newspapers in general. He states: 'Earlymodern news periodicals were an important industry... as a collective memory. They were desired press products for the elite and middle classes: politicians, diplomats, merchants, high-ranking civil servants, clergymen and other more or less educated people.' (3I) To understand Dutch culture, in other words, one can look into these periodical newspapers and digests.

In every chapter, Koopmans reminds the reader of the peculiar role the newspaper had at the time. Newspapers reflected and shaped the culture in which they were read. Reports were generally written by educated but not typically elite men, and they were curated by newspaper publishers with their thumbs firmly on the pulse of their local and state communities. Because newspaper men sought to provide information about which their readers were concerned, these papers offer unique insight into the early-modern world - how information spread, how other places were perceived, even perhaps some of the readers specific values as chapter five suggests. To take one example, Koopmans considers how a united seeming European continent emerged throughout the early modern period. For centuries the continent of Europe was a chaotic, disjointed and bloodstained mess. But with fits and starts that began to transition into a more cohesive entity during the eighteenth century. What changed? Koopmans proposes a fascinating answer: newspapers. As readers began to understand peoples from neighboring European countries, and as news reports were translated and shared across countries, a more united reading market was formed. Newspapers, Koopmans writes, 'helped to shape Europe as a reality,' (I88) helping to bring a shared sense of identity across a disparate continent.

The author crisscrosses Europe throughout the seventeenth and eighteenth century, with newspapers as his key source, all the while not allowing the reader to be left behind. And he regularly ties the specific history of the newspaper to the broader topic of culture and politics. For instance: 'Governments always set great store by the spread of favorable information. To that end many authorities have manipulated the press by only providing positive and focused information, and through censorship.' (79)

Concluding the introduction, Koopmans writes 'I can only hope that this volume will be nothing more than an interim report.' (II) 
Koopmans continues to publish on Dutch printed newspapers, so in that sense it is 'interim.' But this volume is certainly more. It makes available some of his research that was inaccessible to non-Dutch scholars, as it includes two chapters (two and thirteen) that appear here for the first time in English. Its articles and essays represent nearly two decades of careful scholarship that has sought to understand Dutch periodicals as sources for understanding the early-modern and modern world, compiled into one accessible volume.

Thanks are due to the book's publisher, the series and especially the author for making a well-researched, engaging collection of articles available in one source. Seen together, these articles provide a valuable contribution to our understanding of such an important topic: how we came to know ourselves.

Forrest C. Strickland, University of St Andrews 